Вісник Дніпропетровського університету. Біологія. Екологія. - 2008. - Вип. 16, т. 1. - С. 51-56. Visnyk of Dnipropetrovsk University. Biology. Ecology. - 2008. - Vol. 16, N 1. - P. 51-56.

УДК 579+612.017+616.1

О. С. Воронкова, О. А. Сірокваша, Т. М. Полішко, А. І. Вінніков

Дніпропетровський національний університет

\title{
НОРМАЛЬНА МІКРОФЛОРА УРОГЕНІТАЛЬНОГО ТРАКТУ ТА ÏÏ РОЛЬ У ПІДТРИМАННІ ІМУНІТЕТУ СЛИЗОВИХ ОБОЛОНОК
}

\begin{abstract}
Проаналізовано взаємозв'язки мікрофлори та імунологічних механізмів урогенітального тракту. Розглянуто стан нормофлори сечостатевої системи та деякі аспекти імунологічного регулювання складу мікрофлори. Проаналізовано дані про взаємну обумовленість змін у складі мікроорганізмів, що колонізують слизову оболонку репродуктивного тракту, та імунних механізмів, що підтримують сталість мікробіоценозу УГТ.
\end{abstract}

O. S. Voronkova, E. A. Sirokvasha, T. N. Polishko, A. I. Vinnikov

Dnipropetrovsk National University

\section{NORMAL MICROFLORA OF GENITOURINARY TRACT AND ITS ROLE IN SUPPORT OF MUCOUS TUNIC IMMUNITY}

The problem of interaction of microflora and immunological mechanisms of a genitourinary tract are under consideration. Status of normoflora of genitourinary tract and some aspects of immunological regulation of microorganisms composition are presented. Data on reciprocal conditionality of chahges in microorganisms composition, which colonized reproductive tract, and in immune mechanisms supporting the microbiocenosis homeostasis of the genitourinary tract are analysed.

\section{Вступ}

Мікрофлора урогенітального (УГТ) та шлунково-кишкового (ШКТ) трактів безумовно відіграє одну з найвизначніших ролей у підтриманні здоров’я макроорганізму. Обидві системи представлено відкритими порожнинами, які постійно контактують із навколишнім середовищем. Оточення здебільшого представлене мікроорганізмами, частка умовно-патогенних і патогенних серед яких відносно значна. Одну з важливих ролей у захисті слизових оболонок від інфікування патогенними мікроорганізмами відіграє нормальна (фізіологічна, індигенна) мікрофлора, що заселяє даний орган або порожнину $[14 ; 15]$. Протягом еволюції відбувалося формування системи «макроорганізм - мікроорганізми», що врешті-решт призвело до утворення сучасної картини нормофлори. Ендосимбіотичні бактерії колонізують організм людини при народженні та у перші дні існування та зберігаються протягом життя людини. Однак нормофлора - динамічне утворення, співвідношення різних мікроорганізмів змінюються протягом життя. Відомо, що зміни у стані мікрофлори можуть бути обумовлені гормональним статусом, способом життя, станом імунітету тощо.

\section{Мікробіоценоз урогенітального тракту}

Мікробіоценоз є своєрідною індикаторною системою, що здатна реагувати якісними та кількісними зрушеннями на будь-які фізіологічні та патологічні зміни у стані макроорганізму. У свою чергу, зміни мікробіоценозу впливають на стан біотопу [2; 21]. 
Мікробіоценоз складається з постійних мешканців (індигенна або автохтонна мікрофлора) та транзиторних мікроорганізмів (випадкова або алохтонна мікрофлора). Перша група є домінантною за чисельністю клітин, але видове різноманіття ії менш виражене. Друга група включає значно ширший спектр видів, але чисельність їх представників мала, приблизно оцінюється як 3-5 \% від загального вмісту бактерій у відділюваному [12].

Природна мікрофлора містить усі організми, що здатні вижити, адаптуватися та співіснувати в конкретному середовищі, не викликаючи захворювань макроорганізманосія. Багатокомпонентність складу мікробіоценозу забезпечує гнучке пристосування мікроорганізмів до змін середовища. Важливою функцією індигенної мікрофлори $\epsilon$ здійснення ефекту колонізаційної резистентності, тобто вона ефективно запобігає колонізації та розмноженню потенційно патогенних бактерій і навіть зміцнює імунітет [22]. Досягається це наступними шляхами:

- конкуренція за поживні речовини;

- конкуренція у процесі поєднання з рецепторами на поверхні клітин епітелію, яка робить неможливим контакт патогенних бактерій з епітеліальними клітинами, що унеможливлює ініціальні стадії інфікування;

- стимуляція утворення природних антитіл, що перехресно реагують з антигенами багатьох патогенів;

- продукція бактеріоцинів (наприклад коліцину) [21].

Підтриманню колонізаційної резистентності статевих шляхів та піхви сприяє багато факторів. Це здатність мікроорганізмів до утримання на поверхні клітин, синергізм та антагонізм взаємодії мікроорганізмів різних груп, цитоліз відлущених клітин епітелію, фагоцитоз (макрофаги та поліморфноядерні лейкоцити), продукція антимікробних субстанцій (перекисів, органічних кислот, опсонінів, трансферинів, імуноглобулінів тощо), продукція стимуляторів імуногенезу та індукція імунної відповіді тощо $[1 ; 6 ; 9]$. Водночас відомо, що всі представники аутомікрофлори здатні виділяти не лише корисні, а і шкідливі метаболіти та фактори, до яких належать ферменти, що забезпечують персистенцію у макроорганізмі, речовини, що захищають від фагоцитозу та навіть токсини, лізини, аглютиніни тощо [21].

Адгезія мікроорганізмів до клітин епітелію є одним із факторів формування мікробіоценозу, забезпечення його стабільності. Адгезивні процеси переважно залежать від рецепторної активності епітеліоцитів, а рецепторний апарат залежить від гормонального статусу. Підвищення концентрації прогестерону призводить до зменшення прилипання лактобацил і зростання адгезивності патогенних мікроорганізмів. Максимальна адгезивність лактобацил до епітелію спостерігається у період овуляції; мінімальна - у період секреторної фази циклу [8].

Бактеріоцини - один із факторів конкурентоспроможності бактерій. Дія цих сполук спрямована на пригнічення росту конкурентних мікроорганізмів та їх загибель: вона охоплює ензиматичну деградацію ДНК або рибосомної РНК; призводить до утворення каналів у мембрані інтактної клітини, що порушує енергетичний обмін і осморегуляцію. Специфіка індигенної мікрофлори зумовлює опірність слизових оболонок до інфікування. Вона істотно залежить від дієти, санітарних умов, гігієнічних навичок, впливу гормонів. Особливо значним на бактеріальну флору УГТ є вплив естрогенів. Ці гормони індукують у клітинах епітелію піхви підвищений синтез глікогену, який у подальшому метаболізується ацидофільними бактеріями (Lactobacillus acidophilus), що призводить до відносно великого зростання концентрації молочної кислоти (тому $p H$ піхви має значення близько 4,0-4,5). Це запобігає розвитку патогенних мікроорганізмів (особливо грибків). 
За умов порушення нормоценозу може розвинутися потужна імуносупресія. Так, при потраплянні $S$. aureus до організму він провокує імунну відповідь, стимулюючи фагоцитарну та антигенлізуючу дію макрофагів проти своїх антигенів, що водночас послаблює відповідь на інші антигени. Також він виснажує гуморальну ланку імунітету $[10 ; 17]$. Порушення гомеостазу нормальної мікрофлори значно зменшує опірність до інфікування патогенними мікроорганізмами слизових оболонок, полегшує ріст патогенів і може за певних умов призвести до суперінфекції $[5 ; 18 ; 20]$.

\section{Формування мікрофлори урогенітального тракту}

При народженні дитина стерильна, але вже до кінця першої доби життя відбувається іiі колонізація аеробними та анаеробними мікроорганізмами. Частина мікроорганізмів з'являється при проходженні через статеві шляхи матері, частина при грудному годуванні, частина - при диханні, триманні на руках (контакт зі шкірою матері або медичного персоналу). Протягом декількох діб відбувається заселення переважно грампозитивною флорою, що складається з анаеробних бактерій, стафіло- та стрептококів, бактероїдів [14]. У цей же час у вагінальному епітелії відбувається накопичення глікогену, який $є$ субстратом лактобактерій; останні поступово займають домінуюче положення. Лактобактерії, розщеплюючи глікоген, поступово викликають зсув $p H$ до $3,8-4,5$, що призводить до інгібування росту всіх ацидофобних мікроорганізмів. Саме у цей час мікрофлора немовляти має максимальну подібність до мікрофлори здорової дорослої жінки [14; 16].

Однак уже через три тижні після народження відбувається остаточна утилізація материнських естрогенів, епітелій стає тонким, вміст глікогену у ньому зменшується. Це, у свою чергу, викликає зниження кількості лактобактерій, а отже, і зростання $p H$ до 7,0. У складі мікрофлори відзначається домінування облігатно-анаеробних мікроорганізмів [14].

Протягом пубертатного періоду (до активації оваріальної функції) загальна кількість мікроорганізмів стає меншою [2]. Після активації оваріальної функції, тобто коли в організмі з'являються власні естрогени, відбувається формування так званого естроген-стимульованого епітелію. На поверхні таких епітеліоцитів стає більше рецепторів для адгезії лактобацил. Зростає і товщина епітеліального шару. Все це призводить до зростання кількості лактобактерій і встановлення їх домінування, яке в нормі зберігається протягом усього репродуктивного періоду жінки. Особливості метаболізму лактобактерій сприяють зсуву $p H$ у кислий бік (до $3,8-4,5)$ [14; 16$]$.

Кількість лактобацил у піхві здорових жінок становить $10^{5}-10^{7}$ КУО/мл, що складає близько 95 \% від загальної кількості мікроорганізмів у даному біотопі. Усі види лактобацил, що визначаються у піхві жінок, називають флорою Додерляйна. До неї належать такі види роду Lactobacillus як L. acidofilus, L. plantarum, L. casei, L. brevis, L. salivarius та деякі інші $[12 ; 14]$. Переважно це мікроаерофіли [12]. Метаболізм лактобацил є засобом регуляції життєдіяльності всіх інших представників мікрофлори урогенітального тракту (УГТ) [3; 6]. Окрім цих, можливе визначення ще близько 40 видів інших бактерій, сумарна кількість яких становить близько 5 \% від загальної кількості мікроорганізмів [12; 14].

Взагалі у складі мікрофлори піхви здорових невагітних жінок послідовність родів (за зниженням кількості) виглядає так: лактобактерії, біфідобактерії, пептококи, пептострептококи, бактероїди, стафілококи, дифтероїди тощо. Рідше до складу нормофлори в незначних концентраціях входять гарднерели, мобілункуси та мікоплазми [14]. Протя- 
гом життя відмічається переважання облігатно- та факультативно-анаеробної мікрофлори над аеробною [4; 12].

Облігатно-анаеробні біфідобактерії зустрічаються у концентрації 4,7 $\lg$ КУО/мл у середньому (але можливі варіації від $10^{3}-10^{7}$ КУО/мл). Є відомості про те, що клітинна стінка біфідобактерій справляє імуностимулювальний ефект, що забезпечує формування вираженої відповіді на чужорідні антигени.

Більшість виявлених у піхві мікроорганізмів представлена транзиторними видами. Частіше за все виявляють коагулазонегативні стафілококи (у першу чергу Staphylococcus epidermidis), крім того Corynebacterium sp., асоціацію Bacteroides sp. та Prevotella sp., Mycoplasma hominis, що присутні у помірній кількості (менше 4,00 lg КУО/мл). У значно менших концентраціях зустрічають представників родів Micrococcus sp., Propionibacterium sp., Veilonella sp., Eubacterium sp. Зрідка (менше $10 \%$ випадків) виділяють представників родів Clostridium sp., Actinomyces sp., Fusobacterium sp., Ureaplasma urealyticum, Mycoplasma fermentas, S. aureus, Neisseria sp., Escherichia coli та інші коліформні бактерії, Gardnerella vaginalis, Candida sp. [12].

\section{Фактори місцевого імунітету}

Стан місцевого імунітету визначається не лише мікрофлорою, а й деякими іншими факторами - похідними слизової оболонки. Найбільша імунологічна активність спостерігається у шийці матки, яка є граничним органом між порожниною матки та засіяною бактеріями піхвою. У слизовій оболонці шийки матки у вигляді окремих скупчень розташована значна кількість плазматичних клітин, що секретують імуноглобуліни (переважно $M$ та $A$, рідше $G$ класів) [7; 8]. Найзначнішу роль відіграють секреторні імуноглобуліни класу $A[19]$.

Цервікальний слиз також є біологічною рідиною, що містить імунологічні фактори. Склад слизу може змінюватися також залежно від мікробіоценозу піхви. Цервікальний слиз відіграє вирішальну роль у протиінфекційному імунітеті статевої системи жінки (особливо під час вагітності). Із перших діб вагітності в лімфовузлах, що дренують матку, зростає кількість антитілотвірних клітин, які активно виробляють імуноглобуліни $A$ та $G$. У нормі під час вагітності у вагінальному секреті виявляються антитіла до багатьох мікроорганізмів, що свідчить про значну активацію імунітету [7; 8].

Одним з основних факторів індукції та регуляції синтезу імуноглобулінів $є T$-хелпери, які здійснюють цю функцію за рахунок виділення цитокінів. Встановлено, що інтерлейкіни-5 та -6 , що їх виробляють $T$-хелпери-2, викликають процеси термінальної фази диференціації $B$-лімфоцитів саме у $\operatorname{Ig} A$-продукуючі плазматичні клітини $[8 ; 11 ; 17]$. Також із лімфоцитів тут представлена субпопуляція $T$-ефекторів, хоча їх значно менше, ніж хелперів. Лімфоцити 3 фенотипом $C D_{8+}$ здатні до синтезу інтерферону $\gamma[8]$.

Кількість лімфоцитів може змінюватися залежно від мікробного оточення. Встановлено, що при наявності міко- та уреаплазм, а також хламідій зменшується чисельність популяції $T$-клітин, особливо ії субпопуляцій $T$-хелперів та $T$-супресорів. Також знижується кількість $N K$-клітин, натомість кількість $B$-клітин зростає. Отже, вплив інфекційного процесу здебільшого негативний, що робить організм ще менше захищеним від патогену [20].

Крім імуноглобулінів у захисті слизової оболонки бере участь комплемент. Деякі його компоненти (наприклад $C_{3}$ ) синтезуються слизовою оболонкою піхви [7]. Водночас тут синтезується і пропердин, який активує комплемент альтернативним шляхом [8]. 
Також у піхві присутні нейтрофіли, які здійснюють фагоцитоз об'єктів, опсонізованих антитілами, що належать до класу імуноглобулінів $A$.

Ще одним із чинників місцевого імунітету є лактоферин - глікопротеїн, виявлений у секреті більшості залоз екзокринного типу. Він може справляти неспецифічну дію, виступаючи як фактор дозрівання та активації клітин лімфоїдного ряду. Також він може зв'язувати іони $\mathrm{Fe}^{2+}$, що пригнічує ріст мікроорганізмів [8].

\section{Висновки}

Мікробіоценоз урогенітального тракту слід розглядати як один із важливих і невід’ємних компонентів підтримання сталості внутрішнього середовища організму, що функціонально пов'язаний із підтриманням імунологічних механізмів. Порушення у складі мікробіоценозу УГТ можуть бути чинниками інших типів патології, у тому числі не пов'язаних із репродуктивною системою. Регуляторна роль мікрофлори УГТ виходить за межі лише репродуктивної системи. Синтез біологічно активних сполук запобігає колонізації порожнини умовно-патогенною флорою, що запобігає виникненню та прогресуванню дисбіотичних явищ.

\section{Бібліографічні посилання}

1. Адгезивные свойства лактобактерий и эшерихий в различных отделах желудочнокишечного тракта человека в норме и патологии / Е. А. Богданова, Ю. В. Несвижский, А. А. Воробьев, М. В. Брюхова // Вестник Российской АМН. - 2006. - № 1. - С. 35-38.

2. Білько І. П. Нормальна мікрофлора органів дихання, статевих, сечовивідних органів та органів зору і слуху людини // Сімейна медицина. - 2005. - № 1. - С. 52-53.

3. Влияние микробных метаболитов на активность каталазы и рост Staphylococcus aureus 6538 P / О. В. Бухарин, С. В. Черкасов, А. В. Сгибнев и др. // Бюллетень экспериментальной биологии и медицины. - 2000. - № 7. - С. 80-82.

4. Грищенко В. І. Стан клітинної ланки імунітету та цитокінового профілю у вагітних 3 раннім гестозом / В. І. Грищенко, І. О. Кудревич // Педіатрія, акушерство та гінекологія. 2005. - № 5. - C. 67-70.

5. Гусев Е. Ю. Индуцированная Staphylococcus aureus антигенноспецифическая иммуносупрессия / Е. Ю. Гусев, В. Л. Поносов // Журнал микробиологии, эпидемиологии и иммунологии. - 1993. - № 2. - С. 122-124.

6. Долгушин И. И. Гормональная коррекция резидентной микрофлоры влагалища и шейки матки у женщин с хроническими цервицитами / И. И. Долгушин, С. Л. Черных, В. Ф. Долгушина // Журнал микробиологии, эпидемиологии и иммунологии. - 2001. - № 4. - С. 100-104.

7. Долгушина В. Ф. Состояние факторов местной иммунной защиты репродуктивного тракта при вагинозе у беременных / В. Ф. Долгушина, Л. А. Смольникова, И. И. Долгушин // Журнал микробиологии, эпидемиологии и иммунологии. - 2001. - № 4. - С. 89-93.

8. Изменения биологических свойств Staphylococcus epidermidis и Escherichia coli под влиянием метаболитов вагинальных лактобацилл в эксперименте / С. В. Черкасов, Т. М. Забирова, А. В. Сгибнев и др. // Журнал микробиологии, эпидемиологии и иммунологии. 2001. - № 4. - С. 114-116.

9. Лебідь Л. О. Запальні захворювання геніталій у жінок з інфекціями сечової системи // Педіатрія, акушерство та гінекологія. - 2005. - № 3. - С. 129-133.

10. Микробиологические и иммунологические характеристики дисбиотических нарушений биотопов слизистых оболочек респираторного и урогенитального трактов / Е. А. Воропаева, Л. В. Григорович, М. В. Кравцова и др. // Вестник Российской АМН. - 2006. - № 1. - С. 3-5.

11. Назарова Е. К. Микробиоценоз влагалища и его нарушения / Е. К. Назарова, Е. И. Гиммельфарб, Л. Г. Созаева // Клиническая лабораторная диагностика. - 2003. - № 2. - С. 25-32. 
12. Сидорова И. С. Микробиоценоз половых путей женщин репродуктивного возраста / И. С. Сидорова, А. А. Воробьев, Е. И. Боровкова // Акушерство и гинекология. - 2005. № 2. - С. 7-9.

13. Стан місцевого імунітету статевих і сечовивідних шляхів у жінок в нормі та за наявності інфекційної патології / О. В. Ромащенко, А. В. Руденко, Л. О. Лебідь, А. Є. Кузьменко // Педіатрія, акушерство та гінекологія. - 2005. - № 5. - С. 93-97.

14. Туманова Л. С. Стан місцевого імунітету пологових шляхів у вагітних жінок з доброякісною та передраковою патологією шийки матки / Л. Є. Туманова, Т. В. Радиш, О. В. Коломієць // Педіатрія, акушерство та гінекологія. - 2004. - № 1. - С. 107-110.

15. Albayrak N. Bactericidal effects of human oral and urinary system epithelial cells against different Escherichia coli strains / N. Albayrak, D. Biriken, H. Ozenci // Mikrobiol. Bul. 2005. - Vol. 39, N 2. - P. 161-167.

16. An altered immunity hypothesis for the development of symptomatic bacterial vaginosis / S. S. Witkin, I. M. Linhares, P. Giraldo, W. J. Ledger // Clin. Infect. Dis. - 2007. - Vol. 44, N 4. P. 554-557.

17. Asymmetric antibodies $(A A b)$ in the female reproductive tract / S. Blois, A. C. Zenclussen, M. E. Roux et al. // J. Reprod. Immunol. - 2004. - Vol. 64, N 1-2. - P. 31-43.

18. Karag'ozov I. Vaginal ecosystem / I. Karag’ozov, E. Shopova, P. Andreeva // Akush. Ginekol. (Sofia). - 2004. - N 43, Suppl. 3. - P. 34-39.

19. Role of $p H$ as a regulator of vaginal physiological environment / G. B. Melis, M. T. Ibba, B. Steri // Minerva Ginecol. - 2000. - Vol. 52, N 4. - P. 111-121.

20. St John E. Bacterial vaginosis and host immunity / E. St John, D. Mares, G. T. Spear // Curr. HIV/AIDS Rep. - 2007. - Vol. 4, N 1. - P. 22-28.

21. Synergistic immunopotentiating effects induced by $T$-cell and $B$-cell superantigen in mice / T. K. Mondal, D. Bhatta, P. K. Ray, P. Pal // Immunol. Invest. - 2001. - Vol. 30, N 3. - P. 169-180.

22. Witkin S. S. Bacterial flora of the female genital tract: function and immune regulation / S. S. Witkin, I. M. Linhares, P. Giraldo // Best Pract. Res. Clin. Obstet. Gynaecol. - 2007. Vol. 21, N 3. - P. 347-354.

Надійшла до редколегї 10.02.2008 